International Journal of Linguistics, Literature and Translation

ISSN: 2617-0299 (Online); ISSN: 2708-0099 (Print)

DOI: $10.32996 / \mathrm{ijllt}$

Journal Homepage: www.al-kindipublisher.com/index.php/ijltt

IJLLT

\title{
Depiction of Nature in the Poetry of Robert Frost and that of the Romantics: Questing for Similitude and Dissimilitude through a Comparative Analysis
}

\author{
Jannat -E- Hosne Ara 8 (iD) \\ Department of English, Mawlana Bhashani Science and Technology University Santosh, Tangail-1902, Bangladesh \\ $\checkmark$ Corresponding Author: Jannat -E- Hosne Ara, E-mail: jannatjueng@gmail.com
}

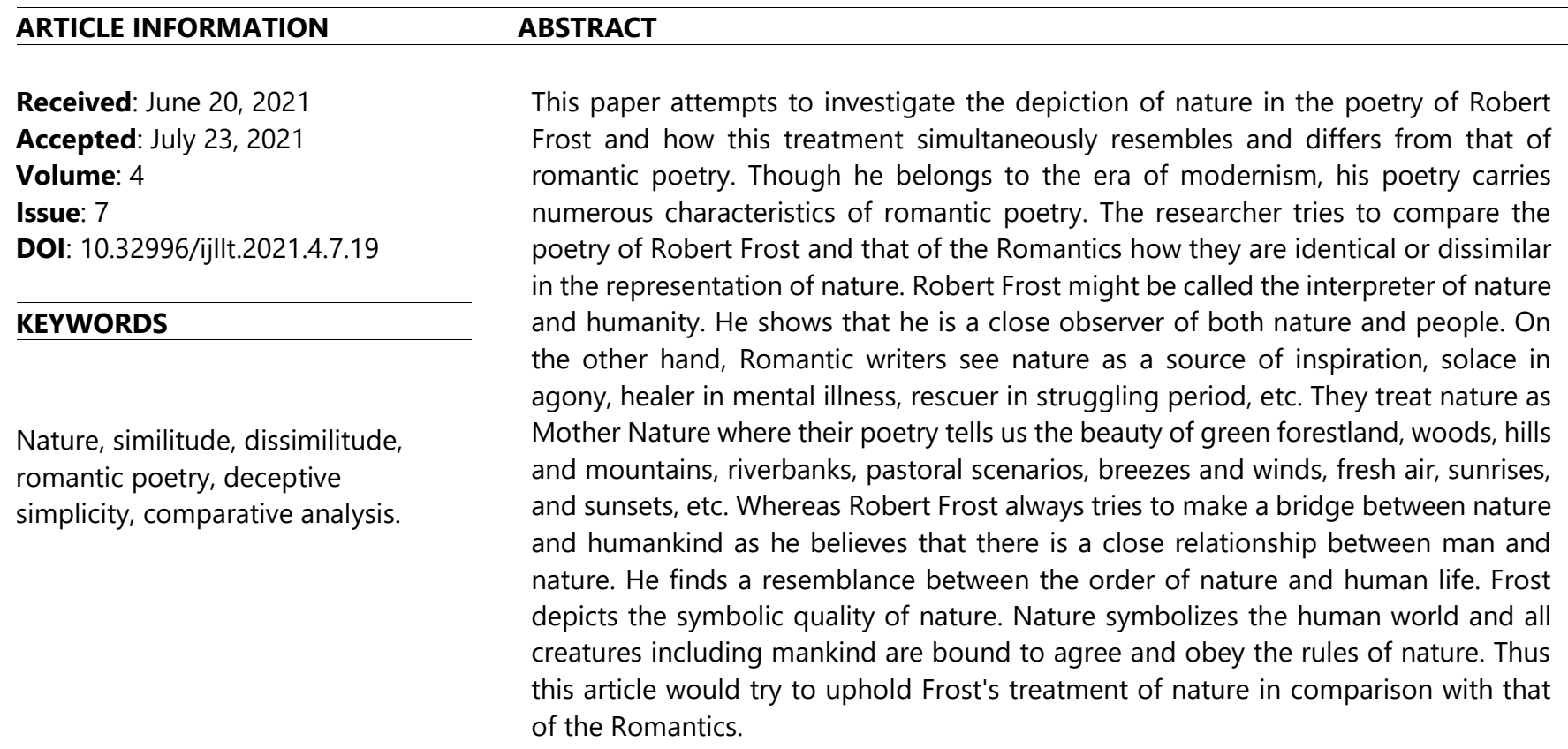

\section{Introduction}

Robert Frost (1874-1963), an American poet who was much admired for three of his outstanding characteristics in his writings such as the depictions of rural life of New England, command of American colloquial speech, and his realistic verse portraying ordinary people in everyday life. He is a four times Pulitzer prize winner. Frost became a poetic force and unofficial "poet laureate" of the United States. His early life was passed in San Francisco, California before his father's demise. Frost moved to Lawrence, Massachusetts with his mother and sister, Jeanie. Then he got admitted into Dartmouth College. After that, he attended Harvard University though dropped out after two years due to illness. In 1900, Frost shifted to New Hampshire with his wife and got a farm purchased by his grandfather for them. But there he lost two of his young children who died. After that, he faced so many challenges in his personal life. Then he started to dwell in the countryside and began setting many of his poems there.

Frost exploded as a writer after his forty. His first poem "My Butterfly: an Elegy", was published in the "The Independent", a weekly literary journal based in New York City. In 1912 Robert Frost decided to sell the farm in New Hampshire and moved his family to England hoping that there would be more publishers. He got his two fellow poets Ezra Pound and Edward Thomas after some days. They played a significant role in Frost's poetic career. They provide strong encouragement and became the first reviewer of his poems. Though Frost got a huge reputation in England, he was able to append a short time here as World War I broke out and he returned to America. In America, Frost was also been reported and well-received by the literary world and flourished his poetic career. Frost read a poem at the inauguration of John F. Kennedy, the President declared of Frost that he has bequeathed his nation a body of imperishable verse from which Americans will forever gain joy and understanding.

\section{K C AL-KINDI CENTER \\ $\mathbf{R}$ D FOR RESEARCH AND DEVELOPMENT}

Your gateway to world-class research

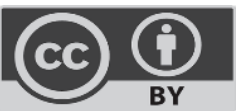

Published by Al-Kindi Center for Research and Development, London, United Kingdom. Copyright (c) the author(s). This open access article is distributed under a Creative Commons Attribution (CC-BY) 4.0 license 


\section{Objectives of the study}

The objective of this paper is to critically interpret Robert Frost's poetry and that of the romantic poets based on their viewpoint of nature. The paper also endeavors to find out the versatile representation of nature in their poetry. The researcher attempts to make a comparative analysis between the poetry of Robert Frost and that of the romantics and also tries to investigate how much similar or dissimilar Frost's treatment of nature is in comparison with romantic poetry.

\section{Methodology}

A qualitative method has been used for conducting the research paper. Several poems of Robert Frost and those of the romantic poets have been used for primary sources and other books and articles have been preferred as secondary sources. A comparative study is an effective method to use to know the authors' attitude about nature in their works.

\section{Findings of the study}

\subsection{Frostian Depiction of Nature}

Frostian depiction of nature is more comprehensive than that of the Romantics. He always attempts to make a connection between nature and human life. The symbolic diction used in his poetry implies different layers of meaning which is very much related to human life.

The poem "The Road Not Taken" (1916) shows that Frost has a deep connection with nature. Here the very word 'Road' symbolizes our 'life'. The inner meaning of the title "The Road Not Taken" implies that the path that we can't choose in our life is 'the road not taken'. Here the poet uses lots of natural imagery like, 'road', 'yellow wood', 'grassy', 'leaves' etc. Through these dictions, Frost wants to reflect some bitter truth of human life. In the poem, the traveler finds himself standing on a fork in the path. He faces trouble as he must choose one path and hesitate to decide the right path. 'Yellow wood' refers to the forest of the autumn season when leaves are falling. It represents a world full of aging people than the poet. Then another word 'grassy' indicates it had not been walked over by many people. The poet describes his feelings about that choice that he had left in the past. In the last stanza, the poet says,

"I shall be telling this with a sigh

Somewhere ages and ages hence;

Two roads diverged in a wood, and I-

I took the one less traveled by,

And that has made all the difference" (Line 16-20).

The path which we have chosen at present indicates our future destination. If we make a wrong decision, there will be no scope to come back. So people must be wise and careful in making the right decision out of the options in every step of their life.

In his poem "Stopping by Woods on a Snowy Evening" (1923), the poet uses the word 'wood' which implies 'deep forest'. The narrator stops beside a wood and continues watching the natural beauty of that snow-covered woods. In the stanza, the narrator's little horse feels strange why his master stops beside this wood instead of the farmhouse. Here he uses the expression 'darkest evening' which could mean the narrator is very depressed for some reason or it is the longest night of that year. He wants to spend a serene moment in a tranquil place to enjoy the snow falling, to soothe his mind, and pass time amidst natural beauty. In the concluding stanza,

"The woods are lovely, dark, and deep

But I have promises to keep

And miles to go before I sleep

And miles to go before I sleep" (Line 16-20).

By the ending lines, it is expressed that the narrator has a strong desire to stay in the dark, tranquil, and silent forest. But at the same time, he feels that he has to go back to society, civilization, and people. He has still some promises to keep, to maintain duties and responsibilities as well.

"Mending Wall" (1916) is another poem where two neighbors are engaged in repairing their wall which separated their properties. Every springtime the stones of the wall start to fall. Here the poet wants to express that nature does not love any boundary or any type of separation. Though there was no harmful animal to damage their apple and pine trees. The speaker is disagreed to keep the wall. But his neighbor feels its significance and says in the poem,

"Good fences make good neighbors" (Line 27). 
Here we observe a clear discord between man and nature. The speaker is young and a modern thinker. But his neighbor keeps old-fashioned ideas and shows an attitude against change-making. In spring, the fallen stones from the wall indicate that nature is against any division and separation. But human beings are creating artificial walls or barriers in nature. Here the word 'wall' symbolizes all kinds of manmade barriers. It indicates the division among nations, classes, races, religions and also makes trouble in mutual understanding and universal brotherhood by creating national, political, and economic barriers.

The poem "Birches" (1914) itself is a name of a slender hardy tree. The whole poem revolves around this birch tree, childhood reminiscence of our poet with it, and some philosophical issues of our life. Here the swinging birch tree recalls the poet's childhood and makes him nostalgic. Our poet is highly nature-oriented and 'the birch tree' here works as a bridge between childhood and adulthood. Swinging on the birch trees is a common pastime of the rural children of New England where our poet spent his childhood. Frost sees the swinging of birch trees as an escape from the bitter realities and hardships of adult life. It is transient condolence where real-life appears hard and harsh. In the poem, he attempts to express his ideas to nature,

"And life is too much like a pathless wood

Where your face burns and tickles with the cobwebs

Broken across it, and one eye is weeping

From a twig's having my lashed opened" (Line 44-47).

The poet seems escapist in one sense as he finds peace in swinging birch trees. From a different perspective, it is noticed that he is a realist too. Because he loves life and it indicates his duties and responsibilities towards life. In poem,

"..........Earth's the right place for love:

I don't know where it's likely to go better" (Line 52-53).

Here his expression is like he would like to go 'toward' heaven by climbing up a birch tree but at the same time, he wants to come back again on earth. Frost does not want to die and to go to heaven. Rather he wants to live in this uncertain world where both earth and heaven might meet. He says,

"I'd like to get away from earth awhile

And then come back to it and begin over" (Line 48-49).

Frost believes that life is beautiful and desirable than heaven. At the age of forty, he writes this poem to reveal the feelings of a middle-aged man who looks both ahead toward death and throwback to childhood. "Birches" ultimately indicates the exploration of the poet's relationship to the Truth.

\subsection{Representation of Nature by the Romantic Poets}

The Romantic period starts after the publication of the Lyrical Ballads in 1798 and ends in 1850. Romanticism is a literary movement that emphasized nature. The writings from this period have several key features. It also focuses on the significance of emotion and artistic freedom in writing. Representation of nature in the romantic poetry is a common characteristic of the romantic period. All the romantic poets love nature and celebrate its majesty from their own perspective. They search for happiness in nature ignoring all sorrows and sufferings of this mundane world.

William Wordsworth is titled as 'a poet of nature'. He is a great devotee and a worshipper of nature. He envisions nature as a living personality. He introduces a different philosophical term in his poetry called pantheism. This belief states that God is present everywhere in every natural thing. Pantheists believe that everything is God, and God is everything. The universe, nature, and God these three are very much interconnected. In his poem "Lines Composed a Few Miles above Tintern Abbey" (1798) he says,

".................... - And I have felt

A presence that disturbs me with the joy

Of elevated thoughts; a sense sublime

Of something far more deeply interfused,

Whose dwelling is the light of setting suns,

And the round ocean and the living air,

And the blue sky, and in the mind of man" (Line 95-101): 
Throughout these quoted lines, William Wordsworth attempts to discover man's relation to nature where man finds God in nature and everywhere feels his existence. The 'presence' or 'God's existence is everywhere like in the sun, the ocean, the sky, the air, and in the man. He conceives the spirit of the universe is prevailing everywhere. He also believes that the company of nature gives joy to the sorrow-stricken heart. It has a great healing influence on pain-afflicted human life. He treats nature as the nurse, the teacher, the guide, and the guardian of his heart. In this poem he also writes:

"The anchor of my purest thoughts, the nurse,

The guide, the guardian of my heart, and soul

Of all my moral being" (Line 109-111).

Besides William Wordsworth believes nature never betray any soul. A human can betray or mistreat his friend. But nature is such a friend who never betrays. Nature can cure all the ailments and sufferings of human beings.

In the first stanza of his poem 'I Wandered Lonely as a Cloud' (1807), William Wordsworth depicts a truly natural environment where he writes,

"Beside the lake, beneath the trees,

Fluttering and dancing in the breeze" (Line 5-6).

Here we find him against urbanization and the modern machine world where he sees man starts to forget the real beauty of nature. He personifies many natural objects in a highly imaginative way. He feels sad because of realizing the gap between nature and humanity.

Shelley represents nature in his poetry in a versatile way. His treatment of nature differs from the other romantics like Wordsworth and Keats. To find some symbols for turning his abstract thoughts and emotions into concrete ones, he roams over outside.

Shelley finds various symbolic meanings in his poem "Ode to the West Wind" (1820). He has a visionary concept and also prophetic insight. He tries to find a similarity between natural change and human society. The wind is a symbol of change, a transition in nature that works simultaneously both as a destroyer and a preserver. This represents Shelley's own aim and aspiration to change and reform society. He says,

"Wild Spirit, which art moving everywhere;

Destroyer and preserver; hear, oh hear" (Line 13-14)!

The Wind sweeps off the dead leaves to make room for the fresh colour and fragrance of spring. Just like he aspires man will also keep apart all of his sorrows and sufferings from their society. Man would take a lesson and bring a change in his life according to the transformation of nature. Shelley also wants to share and influence his new ideas of love and freedom. He prophesizes,

"The trumpet of a prophecy! O Wind,

If Winter comes, can Spring be far behind" (Line 69-70)?

He desires that the sufferings of mankind will be replaced by pure happiness. Shelley has the hope of a golden age through the regeneration of mankind. That is why he feels the need to play the role of a reformer.

Similarly, in "The Cloud" (1820) which changes but never dies here is found Shelley's yearn for immortality. He says,

"I change, but I cannot die" (Line 76).

Thus his cloud is not only capable of changing its form but also incapable of dying as well. His belief in immortality is also found in Adonais when he tells the immortality of stars:

“The sun comes forth, and many reptiles spawn;

He sets, and each ephemeral insect then

Is gathered into death without dawn,

And the immortal stars awake again" (Line 253-256).

Sometimes his portrayal of imagery can produce a pictorial quality as we see in "The Cloud" it is really vivid and picturesque. 
"The sanguine sunrise, with his meteor eyes,

And his burning plumes Outspread,

Leaps on the back of my sailing rack,

When the morning star shines dead" (Line 31-34);

Like the cloud, Shelley himself wants to transcend the limitations of life. He feels his life is boundless and finds its dynamism. The sky, stars, sun, moon, wind, and the river all these elements of nature have frequently been used by Shelley as symbols of eternity.

In "To a Skylark" (1820), the skylark symbolizes his hopefulness of the liberation of mankind. In Adonais, for instance, morning, thunder, ocean, winds, echo, spring, and others are all impersonated and made to participate in the mourning for Keats. In his poetry, he personifies the forces of nature and gives to each one of them Individuality, feelings, and capacity to act.

Keats's sensibility of Nature is very different from that of the other romantics. He remains quite uninfluenced by Wordsworth, Coleridge Shelley, and the rests. He loves Nature because of her external charm and beauty not getting inspired by its spiritual or divine significance. Sensuousness is a quality in poetry which affects the senses i.e. hearing, seeing, touching, smelling, and tasting. Sensuous poetry gives more delight to the senses rather than throwing any philosophical ideas. Keats is the worshiper of beauty and searches for beauty everywhere. He loves nature for its own sake. The nucleus of Keats' poetry is sensuousness.

Then, of course, we have the "To Autumn" (2001) in which we have beautiful pictures of autumn's fruits as well as songs. The ripe apples, the swollen gourd, the sweet kernel in the hazels, the honey in beehives have all a rich sensuous appeal. Perhaps the best example of Keats sensuousness lies in this poem. In this ode, the autumn season is described in sensuous terms in which all senses are called forth.

"Season of mists and mellow fruitfulness

Close bosom-friend of the maturing sun" (Line 1-2);

For Keats, Autumn is the season of apples on mossed cottage trees, of fruits that are ripe to the core, and of later flowers for bees. Thus autumn to Keats is full of pictures of delights of sense. There is the ripe fruit and ripe grains and also there is music that appeals to the ear. In the poem "To Autumn" Keats reflects on the cycle of life and the interconnectedness of maturity, death, and rebirth as one season gives way to another. The poem is full of the feeling of nature's generosity.

In the "Ode to a Nightingale" we have a couple of remarkable Nature-pictures owing to Keats's delight in the purely sensuous appeal of Nature. One is the picture of the moon shining in the sky while there is darkness on the grassy floor of the forest:

"And haply the Queen-Moon is on her throne,

Cluster'd around by all her starry Fays" (Line 36-37);

In "Ode to a Nightingale", hearing the bird's song causes the speaker to reflect on the immortality of art and the mortality of humans. He looks with child-like delight at the objects of nature. In his poem, he writes:

"My heart aches, and a drowsy numbness pains

My sense, as though of hemlock I had drunk,

Or emptied some dull opiate to the drains" (Line 1-3);

Keats is astonished to see the happiness of the Nightingale. Before hearing the song of the bird, he tried many ways of forgetting worries. Keats believed he has either been poisoned or is influenced by the drug. But Keats felt a tranquil and continual joy in the song of Nightingale and makes him completely happy. It indicates to unite with nature gives eternal happiness for mankind.

In the "Ode to Psyche" (2001), we again have a couple of exquisite pictures of Nature. Cupid and Psyche are seen lying side by side where there is deep grass below, the hushed, cool-rooted, fragrant-eyed flowers of variant colours. It is an eye-soothing picture.

\section{Comparative Discussion}

The theme of nature is a very common phenomenon that we find more or less in every poet's writings. It is a universal element that is why every writer tries to incorporate it in their writings. But the important thing is the way they treat nature seems nonidentical. They see the same nature, but their poetry is versatile and unique.

Both similarity and dissimilarity are found in the study of Frost's poetry and that of the romantics. William Wordsworth the seniormost poet of the romantic period finds nature as his healer, nurse, guide, and teacher. He thinks that nature can give him console 
and peace in his sorrow-stricken heart. Further, he shows him as a pantheist where he sees God in every creature everywhere. Everything is God to him.

On the other side, Robert Frost always tries to find identicalness between the function of nature and mankind. He sees the reflection of nature in human life and seeks the spiritual connection. Frost uses very simple words in his poetry. But these are impregnated with numerous deep meanings. This type of writings is called deceptive simplicity. It seems his dictions are very simple and common. But their underlying meaning is filled with the complexities and untold things of rural life in the guise of plain words.

Shrestha (2020) thinks that Frost presented the natural world in the form of the source which inspires individuals for the deep metaphysical thought as it is seen in 'Birches' and 'The Sound of Trees'. Nature is not simply a background for poetry, but rather a central character in his works. Birches, one of the best-known poems is not about simply birches, mainly, it's about the desire of escaping from this mundane world.

Wordsworth considers poetry as the product of personal, spiritual, or mystical experience like he says in Preface to Lyrical Ballads (1801), "Poetry is the spontaneous overflow of powerful feelings; it takes its origin from emotion recollected in tranquility." On this idea, Frost has a very different view. He thinks that poetry begins in very conscious thought and ends subconsciously. Wordsworth finds a very good relationship between man and nature. He sees no hostility here rather finds the supreme peace in a touch of nature. But in the case of Frost, it is not like this. Rather he found a conflict here as we see in his poem "Mending Wall" where two neighbors keep opposite notions about repairing the wall. Here we see the conflicting nature of human nature.

In comparison with John Keats, Frost can be considered as an escapist rather than a pessimist. They temporarily sink into the heart of nature. But after a certain period, they come to reality. In "Ode to a Nightingale", Keats imagines that the bird Nightingale is free from all the sorrows and sufferings as man faces. Though he realizes that escape from the realities of life is not possible, he tries to find solace and peace in the song of the bird Nightingale. Similarly, in the poetry of Frost, sometimes he seems like an escapist. In "Stopping by Woods on a Snowy Evening" he writes in the last line, "And miles to go before I sleep". This line indicates that he goes to nature for temporary peace and wants to go back to obey his mundane duties and responsibilities. In "Birches" we observe the same thing as he desires to reach heaven with the swinging birch trees. At the same time, he desires to come back to earth.

When Frost and Shelley are thought together based on their representation of nature in their poetry, here we find some similarities between both of them. In Frost's "Mending Wall", we see the speaker goes against keeping any wall between his neighbors' property. He is unwilling to break the rules of nature. Nature does not like any division and it wants its freedom. In the case of Shelley, in "Ode to the West Wind", he also tries to show the beauty and transformation of nature in various seasons. The way he explains natural changes also indicates his reformist attitude. He is not a conservative rather he wants to sing for the new thoughts, new world. As Shelley was inspired by French Revolution, he has a passion for reforming the world. He is considered a revolutionary poet and fought against conservative politics and values. This reflection is always found in Shelley's poetry.

Zhang et al. (2017) find that Frost shares with Wordsworth and Emerson a keen interest in nature. But Frost's perception of nature is more complicated than theirs. Nature is employed as a metaphor in many of his poems which sometimes tries to make an analogy to human life.

Nolan (1942) writes that Robert Frost has been called the interpreter of New England, but he might also be called the interpreter of nature and humanity as a whole. His poetry shows that he is a close observer of both nature and people and that he portrays their fundamental elements.

\section{Conclusion}

As per the discussion above, it can be understood that the treatment of nature in Frost's poetry carries both similarities and dissimilarities in comparison with the poetry of the Romantics. Nature plays a central character in Frost's poetry. Frost uses such types of imagery where he attempts to show both the dark and bright sides of nature. He used 'crow' in one of his poems. It is associated with the dark condition of something where other writers use 'singing Nightingale' and 'White doves' in their poems. In this manner, Frost is considered to be very unique in thought. Frost is not affected by wartime or political changes as his poetry indicates. His main themes are his great love of Nature and his own philosophy. Frost sees and shows nature in a very different way which is very much related to our life and reality.

To wrap up, it can easily be understood that this article tries to critically analyze the poetry of Robert Frost and that of the romantics how they depict nature in their poems. To conduct this comparison, the researcher attempts to trace both similarities and dissimilarities in their treatment of nature. Frost does not see nature from the pantheist point of view like Wordsworth. Rather he believes that man should live in harmony with nature. Some of his poems give us his escapist vibes to nature as Keats had. Frost is a man of maintaining responsibility and duty-bound to Earth. Frost's poetry begins in delight and ends in wisdom. He uses 
deceptive plainness in his poetry. In deceptive simplicity, Frost reveals the complexities of rural life in the guise of simple words. He uses symbols and imagery from nature to reveal the hidden meanings. The content of his poetry is about rural landscape, wildlife and the subjects of his poems are about the farmers and workers. Like the Romantics, Frost also seeks solace and delight in nature. But similarly, he is conscious about obeying his duty towards Earth. This article can create a way to understand and analyze the similarities and dissimilarities in the treatment of nature between the poetry of Robert Frost and that of the romantics. It tries to critically investigate the depiction of nature through choosing some of the significant poems of the romantic poets and that of Robert Frosts'. Thus this work can contribute to further studies on that topic and also can enrich this research area.

\section{References}

[1] Frost, R. (1914). Mending Wall. North of Boston. London: David Nutt (New York: Holt, 1914)

[2] Frost, R. (1916). Birches. Mountain Interval. New York: Holt

[3] Frost, R. (1916). The Road Not Taken. Mountain Interval. New York: Holt

[4] Frost, R. (1923.) Stopping by Woods on a Snowy Evening. New Hampshire. New York: Holt (London: Grant Richards, 1924)

[5] Keats, J. (2001). Complete poems and selected letters of John Keats. New York: Modern Library.

[6] Nolan, C. E. (1942). Robert Frost : His treatment of nature and humanity. Boston University Libraries. https://hdl.handle.net/2144/7542

[7] Shelley, P. B. (1820). The Cloud. Prometheus Unbound, A Lyrical Drama, in Four Acts, With Other Poems. Charles and James Ollier, London.

[8] Shelley, P. B. (1820). To A Skylark. Prometheus Unbound, A Lyrical Drama, in Four Acts, With Other Poems. Charles and James Ollier, London.

[9] Shelley, P. B. (1820). Ode to the West Wind. Prometheus Unbound, A Lyrical Drama, in Four Acts, With Other Poems. Charles and James Ollier, London.

[10] Shrestha, M. (2020). Nature: A Notable Feature of Robert Frost's poetry. Journal of Advanced Academic Research, 7(1), 37-50. https://doi.org/10.3126/jaar.v7i1.35466

[11] Wordsworth, W. (1801). Preface to Lyrical Ballads. London.

[12] Wordsworth, W. (1807). I Wandered Lonely as a Cloud. Poems, in Two Volumes. Broadview Press.

[13] Wordsworth, W., \& Coleridge, S. T. (1798). Lines Composed a Few Miles above Tintern Abbey. Lyrical ballads, with a few other poems. Bristol.

[14] Zhang, Y., Ding, W. \& Jia, L. (2017). Analysis on Nature in Robert Frost's Poetry. English Language, Literature and Culture, 2(3), 25-30. doi: 10.11648/j.elle.20170203.11 